UDK 339.924(4-672EU:497.11)

339.924(4-672EU:497.5)

Biblid 0543-3657, 72 (2021)

God. LXXII, br. 1183, str. 53-68

Izvorni naučni rad

Primljen: 16.8.2021.

Prihvaćen: 12.10.2021.

doi: https://doi.org/10.18485/iipe_mp.2021.72.1183.3

Isidora POP-LAZIĆ

\title{
Specifičnosti i tok pristupnih pregovora Srbije i Hrvatske za članstvo u Evropskoj uniji - implikacije na bilateralne odnose
}

\begin{abstract}
SAŽETAK
U radu se analiziraju razlike u pristupnim pregovorima Srbije i Hrvatske za članstvo u Evropskoj uniji, a koje su u najvećoj meri uticale na dosadašnji tok $\mathrm{i}$ ishode pregovora, ali i bilateralne odnose dve države. Iako su pregovori nominalno pogodan okvir za rešavanje otvorenih pitanja između država kandidata, ni Srbija ni Hrvatska u nedostatku političke volje nisu iskoristile taj kapacitet. Srbija ima najviše otvorenih pitanja upravo sa susednom Hrvatskom, a dinamika odnosa znatno je promenjena stupanjem Hrvatske u članstvo 2013. godine dajući joj povlašćeni položaj u odnosu na Srbiju kao kandidata. Osnovna teza rada je da je Evropska unija u pregovorima sa Srbijom, uzdižući normalizaciju odnosa između Beograda i Prištine iznad bilateralnih odnosa sa zemljama $u$ regionu, doprinela $u$ najmanju ruku tome da se održi status quo u rešavanju otvorenih pitanja sa Hrvatskom (pitanja manjina, nestalih, prognanih i interno raseljenih lica, demarkacija granice na Dunavu, sukcesija i mnoga druga). Ne treba izgubiti iz vida da odnosi Srbije i Hrvatske nisu čisto bilateralni, već imaju svoju dimenziju i u Bosni i Hercegovini, što dodatno ističe značaj za unapređenjem odnosa u cilju dugoročnog mira i stabilnosti na Balkanu.
\end{abstract}

\footnotetext{
${ }^{1}$ Isidora Pop-Lazić, istraživač-pripravnik, Institut za međunarodnu politiku i privredu, Beograd, e-mail: isidora@diplomacy.bg.ac.rs

Rad je nastao u okviru projekta „Srbija i izazovi u međunarodnim odnosima 2021. godine", koji finansira Ministarstvo prosvete, nauke i tehnološkog razvoja Republike Srbije, a realizuje Institut za međunarodnu politiku i privredu tokom 2021. godine.
} 
Razloge za ovakvo pozicioniranje Unije vidimo u njenim nastojanjima da poveća svoju ulogu u regionu. Svojim angažovanjem u rešavanju kosovskog pitanja, a usled smanjenja njene takozvane transformativne moći, EU je dostigla maksimum svojih kapaciteta, zbog čega je zauzela pasivan stav kada su u pitanju bilateralni sporovi. Dvostruki aršini kojima se sporadično služila EU, kada su u pitanju Srbija i Hrvatska, bili su vidljivi još u Procesu stabilizacije i pridruživanja koji predhodi pregovaračkom procesu, o čemu će biti reči u prvom delu rada. Iako uslovi za stupanje u članstvo nisu formalno promenjeni, jesu suštinski. U tim promenama se nalazi, između ostalog, razlog sporog napretka Srbije ka članstvu u EU koji je u osnovi političke prirode. Te promene biće predstavljene u drugom delu rada. Na kraju pokušaćemo vrednosno da ocenimo da li je ovakvo delovanje EU, ali i sam pregovarački proces, pozitivno ili negativno uticao na razvoj dobrosusedskih odnosa dve države.

Ključne reči: Evropska unija, Srbija, Hrvatska, pregovarački proces, pristupni pregovori, članstvo, kriterijumi, bilateralni odnosi

\section{Razvoj politike proširenja EU - kriterijumi za članstvo}

Manje države prirodno teže saradnji i uključivanju u političke i bezbednosne strukture $\mathrm{u}$ okviru kojih će, kako se smatra, lakše moći da ostvare svoje ciljeve i propagiraju svoje interese. Članstvom u brojnim međunarodnim organizacijama one to čine daleko uspešnije nego što bi to mogle samostalno. U tom svetlu posmatramo i težnje država bivše Jugoslavije da postanu članice Evropske unije (u daljem tekstu EU ili Unija). Taj cilj su do danas dosegle Slovenija i Hrvatska, kao ujedno i poslednja država koja je stupila u članstvo. Politika proširenja se menjala tokom godina, i kako je interesovanje za Uniju raslo tako je politika proširenja postajala složenija. Menjao se čak i naziv, pa se danas zvanično zove "politika susedstva i pregovora o proširenju". Ova naizgled nebitna terminološka promena zapravo ukazuje i na promenu pristupa i (ne)spremnost Unije na proširenje. Imajući u vidu dugogodišnju neizvesnost pristupanja EU ova promena nas navodi na pitanje - da li su pregovori sami po sebi cilj kako bi Unija zadržala poziciju moći, a bez stvarne namere da integriše preostale države tzv. Zapadnog Balkana.

Pravni osnov politike proširenja je član 49 Ugovora o Evropskoj uniji, u kome se navodi da svaka evropska zemlja može podneti zahtev za članstvo ako poštuje principe slobode i demokratije, ljudska prava i osnovne slobode, kao i vladavinu prava. ${ }^{2}$ Pored toga, kriterijumima iz

${ }^{2}$ Consolidated Version of Treaty on European Union, Official Journal of the European Union, C 326/13, 26.10.2012, art. 49. Dostupno na: https:/ / eur-lex.europa.eu/resource.html? uri=cellar:2bf140bf-a3f8-4ab2-b506-fd71826e6da6.0023.02/DOC_1\&format=PDF, 54 pristupljeno: 22.10.2020. 
Kopenhagena (1993. godine) postavljen je osnov za politiku uslovljavanja koja je i danas sastavni deo politike proširenja. Kriterijumi iz Kopenhagena mogu se podeliti na: političke (stabilnost institucija koje garantuju demokratiju, vladavinu prava, ljudska prava i poštovanje i zaštitu manjina), ekonomske (funkcionalna tržišna privreda i sposobnost da se nosi sa tržišnim pritiscima unutar jedinstvenog tržišta) i pravne (Acquis communautaire sposobnost implementacije pravnih tekovina Unije). ${ }^{3}$ Usvajanjem ovih kriterijuma i formalno je počela transformacija procesa pristupanja, iz procedure priključivanja EU u politiku promovisanja politizovanih normi. Pored uslova koje mora ispuniti država kandidat, često je prenebregnut kriterijum koji se tiče spremnosti EU da prihvati, odnosno integriše nove članice. Iako se često u javnosti može čuti kako će države kandidati biti primljene nakon što ispune sve uslove, i da napredak isključivo zavisi od sprovedenih reformi, praksa nam govori da mora postojati politička spremnost da do proširenja dođe. Dakle, pristupanje zavisi pre svega od političkih odnosa u EU, a potom i od države kandidata. Možemo slobodno reći da zamor od proširenja postaje hroničan, te da se kao posledica javlja i zamor od iščekivanja članstva. Ovaj jaz ispunjava se drugim akterima na međunarodnoj sceni, zbog čega se često mogu čuti disonantni tonovi od strane EU, poput onih da se treba rešiti „malignog uticaja trećih zemalja”. ${ }^{4}$ Primera radi, usklađenost spoljne politike Srbije sa zajedničkom spoljnom i bezbednosnom politikom EU (ZSBP) - poglavlje 31 ocenjuje se kao polovična. Nakon potpisivanja strateških sporazuma sa NR Kinom i Ruskom Federacijom beleži se konstantan pad usklađenosti sa ZSBP. Najveću usklađenost Srbija je imala 2012. godine kada je ona iznosila 98\%, a nakon toga beleži tendenciju opadanja, da bi tek 2019. godine zabeležila blagi rast sa $52 \%$ na $57 \%$ usklađenosti. ${ }^{5}$ U zemljama sa ograničenim suverenitetom prisustvo spoljnih aktera menja unutrašnju političku

${ }^{3}$ Copenhagen European Council (21-22 June 1993), Conclusions of the Presidency, E.U. Bull., supp. 6/1993 (June 1993).

${ }^{4}$ European Commission Communication from the Commission to the European Parliament, the Council, the European Economic and Social Committee and the Committee of the Regions - Enhancing the accession process - A credible EU perspective for the Western Balkan, Brussels, 5.2.2020. Dostupno na: https://ec.europa.eu/ neighbourhood-enlargement/sites/near/files/enlargement-methodology_en.pdf

${ }^{5}$ Vidi: Igor Novaković, Natan Albahari i Jovana Bogosavljević, Analiza usaglašavanja Srbije sa spoljnopolitičkim deklaracijama i merama Evropske unije tokom 2018. godine, ISAC Fond, Beograd, 2019. godine. Dostupno na: http:/ / www.isac-fund.org/wp-content/uploads/ 2019/02/ISAC_ZSBP-Analiza-2018.pdf

Napomena: analiza za 2019. godinu dostupna je samo na engleskom jeziku na sledećem linku: https:/ / www.isac-fund.org/wp-content/uploads/2020/02/ISAC-CFSP-Analysis2019-1.pdf 
dinamiku $u$ procesu donošenja odluka $u$ vezi sa usvajanjem $i / i l i$ sprovođenjem zahteva ispostavljenih od strane EU. ${ }^{6}$

Francuska je u novembru 2019. godine podnela non-paper o reformi procesa proširenja, da bi usledio non-paper još devet država članica narednog meseca iste godine. Početkom tekuće godine usvojena je nova metodologija pristupanja EU, a deset meseci nakon njenog predstavljanja i dalje nisu poznata pravila za primenu. Ovu inicijativu pokrenula je Francuska nakon što je blokirala pregovore sa Severnom Makedonijom i Albanijom, uprkos činjenici da je rešen višedecenijski spor oko imena Makedonije (Prespanskim sporazumom). Spor Makedonije i Grčke takođe je, kao i pitanje Kosova i Metohije, identitetskog karaktera. Ovakav ishod može biti zabrinjavajući pokazatelj, da čak i ako Srbija ispuni sve kriterijume koji se tiču normalizacije odnosa Beograda i Prištine to neće rezultirati njenim članstvom u EU. Nova metodologija neće se po automatizmu primenjivati na Srbiju, već će države kandidati imati pravo da izaberu da li će je prihvatiti ili ne. Ona predviđa da pregovaračka poglavlja budu podeljena u šest tematskih klastera, čime će se srodna poglavlja u okviru klastera otvarati istovremeno, a poglavlja 23 i 24 ostaju blokirajuća. Druga promena odnosi se na mogućnost "delimične integracije" koja predviđa mogućnost da se država, u skladu sa napretkom u pregovorima, postepeno uključi u neke javne politike i programe EU. Predviđeno je da se odvoji više novca iz fondova EU u slučaju dobrih rezultata, ali se uvodi i reverzibilna komponenta koja podrazumeva da se pregovori mogu vratiti korak ili dva unazad ako rezultati izostanu. Ukoliko Srbija odluči da prihvati novu metodologiju važno je pitanje kako će se vrednovati dosadašnji napredak po poglavljima. Ove godine Srbija nije otvorila nijedno novo poglavlje, a takođe nijedno od pet koja su već otvorena nije zatvorila. Ipak, razloge ne možemo tražiti u novoj metodologiji pregovora, jer Srbija ima precizno definisana pravila po kojima pregovara sve dok se neka nova ne usvoje i postanu važeća. To nam govori da razlozi nisu tehničke već političke prirode. Jedan od razloga za izostanak rezultata svakako možemo tražiti u nezadovoljstvu država članica učinkom Srbije u sprovođenju reformi. Ne treba zaboraviti da Srbija nema šefa pregovaračkog tima od septembra 2019. godine, kada je sa te funkcije otišla Tanja Miščević, a taj problem konstatuje i izveštaj o napretku Srbije za 2020. godinu.

\section{Srbija i Hroatska - proces pridruživanja EU}

Proces stabilizacije i pridruživanja (PSP) je politički okvir, odnosno strategija Evropske unije za unapređenje odnosa između država „zapadnog

${ }^{6}$ Srđan Blagovčanin, Evropska unija i Bosna i Hercegovina: Građenje države kroz proces evropskih integracija, Friedrich-Ebert-Stiftung, Sarajevo, 2016, str. 15. 
Balkana" (Albanija, Bosna i Hercegovina, Hrvatska, Severna Makedonija, Srbija i Crna Gora) i EU.? Proces reafirmiše ciljeve dotadašnje politike EU s ciljem da se učini izvesnijom evropska perspektiva regiona. Strategija stabilizacije i pridruživanja otvorena je 1999. godine u vreme kada je Savezna Republika Jugoslavija (SRJ) bila izložena NATO agresiji, da bi nakon petooktobarskih promena ušla u sam proces. Kako bi se ojačali započeti reformski procesi, Evropska unija je državama „zapadnog Balkana" dodelila status potencijalnih kandidata za prijem u Evropsku uniju na samitu u Santa Maria da Feiri juna 2000. godine, a zatim predložila neke podsticajne instrumente, među kojima je i pokretanje posebnog političkog foruma koji se ogleda u održavanju periodičnih samita šefova država ili vlada država članica Evropske unije i država tzv. „zapadnog Balkana”. 8 Prvi takav samit, na kome je SRJ zvanično učestvovala, održan je upravo u Zagrebu u novembru 2000. godine. To je bio prvi samit koji je održan van teritorija država članica. Samit u Zagrebu označio je ulazak i Srbije i Hrvatske $u$ proces evropskih integracija. U završnoj deklaraciji sa pomenutog samita razvoj regionalne saradnje ističe kao prioritet. ${ }^{9}$ Tada pitanje Kosova još uvek nije bilo aktuelno, pošto je samoproglašena nezavisnost proglašena osam godina kasije nakon čega se prioriteti postepeno menjaju, pa čak i kada se kaže regionalna saradnja primarno se misli na odnose Beograda i Prištine, a videćemo u nastavku i zašto je to neprihvatljivo.

Iako su istovremeno krenule put kojim su se kretale Srbija i Hrvatska, kao i dinamika napretka, bitno su se razlikovali. Potpisivanjem, odnosno ratifikacijom Sporazuma o stabilizaciji i pridruživanju (SSP) uspostavlja se odnos pridruživanja među ugovornim partnerima, najpovlašćeniji odnos koji prema Evropskoj uniji može imati država koja nije njena članica. Regionalna saradnja, kao formalni uslov za napredak u procesu evropskih integracija, uvedena je upravo sporazumima o Stabilizaciji i pridruživanju. Postkomunističke srednjoevropske države nisu imale formalnu obavezu u svojim Evropskim ugovorima da sarađuju sa susedima. ${ }^{10}$ Hrvatska je potpisala SSP krajem oktobra 2001. godine, dok je Srbija to učinila tek u

\footnotetext{
${ }^{7}$ Termin „zapadni Balkan” u ovom radu pišemo pod znacima navoda i malim početnim slovom jer želimo da naglasimo političku prirodu ovog sada već opšteprihvaćenog termina, jer u geografskom smislu taj pojam nije adekvatan i prihvatljiv. Više o kritici pojma "zapadni Balkan” u: Nacionalni interes, godina VIII, vol. 15, br. 3/2012.

${ }^{8}$ Dr Vladimir Međak, Branko Budimir, Vodič kroz pristupanje Srbije Evropskoj uniji, ISAC Fond, Beograd, 2013, str. 22.

${ }^{9}$ The Declaration of the Zagreb Summit, European Commision, 24 November 2000. art. 3.

${ }^{10}$ Jovan Teokarević, „Skroman napredak ka sve manje poželjnoj Evropskoj uniji: Zapadni Balkan u evropskim integracijama 2015-2016. godine", Spoljnopolitičke sveske, broj: 01/16, str. 12.
} 
aprilu 2008. godine. U to vrme Hrvatska je već uveliko bila kandidat i otvorila čak 16 pregovaračkih poglavlja, što približno odgovara pregovaračkoj poziciji Srbije danas. Razlozi ovako sporog napredovanja Srbije leže, između ostalog, u kompleksnosti odnosa u tadašnjoj Državnoj zajednici Srbije i Crne Gore. Zbog nemogućnosti uspostavljanja jedinstvenog tržišta usvojen je pristup dvostrukog koloseka (twin-track), koji podrazumeva da se na nivou državne zajednice pregovaraju politički aspekti SSP, a da Srbija i Crna Gora zasebno pregovaraju trgovinski deo sporazuma. Pored toga, pregovori su otkazani, odnosno prekinuti (called off) zbog, kako je ocenjeno, nezadovoljavajuće saradnje sa Hagom (u periodu od maja 2006. do juna 2007. godine), a Crna Gora je u tom periodu proglasila samostalnost. I Hrvatska se suočila sa istim problemom, ali u kasnijoj fazi. Pristupni pregovori odloženi su (umesto u martu počeli su u oktobru 2005. godine) iz istog razloga - nedovoljne saradnje sa Hagom. Iako je povod za suspenziju pregovora bio isti u oba slučaja, ovde možemo uočiti jasnu nedoslednost EU po pitanju značaja saradnje sa Haškim tribunalom u procesu pridruživanja (Srbija), odnosno pristupanja (Hrvatska). Srbiji dakle nije bilo dozvoljeno da dobije status kandidata zbog izostanka saradnje sa Hagom, dok je Hrvatska uveliko imala status kandidata ali joj je samo odložen početak pregovora. Ono što je za Srbiju bila prepreka za sticanje statusa kandidata nije bila prepreka za Hrvatsku. Srbija je status kandidata dobila u martu 2012. godine, tek nakon što su Beograd i Priština 24. februara 2012. godine postigli Dogovor o regionalnom predstavljanju i saradnji koji je prihvaćen na privremenoj osnovi. Prema odredbama ovog dogovora $u$ okviru regionalne saradnje dozvoljeno je korišćenje naziva Kosovo sa zvezdicom $(*)$, pri čemu kao naznaka stoji „ovaj naziv je bez prejudiciranja statusa i u skladu je sa Rezolucijom Saveta bezbednosti Ujedinjenih nacija 1244 i mišljenjem Međunarodnog suda pravde o deklaraciji o nezavisnosti Kosova" ${ }^{11}$ Na osnovu prethodno navedenog možemo izvući nedvosmisleni zaključak da je pitanje Kosova postalo i ostalo od najveće važnosti za napredak Srbije u EU integracijama.

\section{Karakteristike pregovaračkih procesa dve države}

Evropska unija je do sada imala sedam talasa proširenja, a politika proširenja se usložnjavala kako je broj članica rastao. Dakle, u pitanju je dinamičan proces koji se konstantno nadograđuje. Iako je do tada bilo karakteristično da više država pristupi Uniji istovremeno, Hrvatska je ušla

${ }^{11}$ Dogovor o regionalnom predstavljanju i saradnji (2012.), čl. 3, Zvanična Internet prezentacija Vlade Republike Srbije. Dostupno na: https:/ / www.srbija.gov.rs/kosovometohija/168200, pristupljeno: 18.8.2020. 
u EU sama, što je prvi takav slučaj nakon pristupanja Grčke 1981. godine. To u praksi znači da nije imao ko da je usporava, niti je imala s kim da se poredi. Srbija u pretpristupnim pregovorima podržava tzv. „princip regate”, koji podrazumeva da se prati individualni napredak svake države nasuprot grupnog pristupanja koji se naziva „princip konvoja”. Pored očiglednih prednosti, kao glavna kritika ovog principa ističe se mogućnost sabotaže pregovaračkih procesa drugih država regiona. Kako države na Balkanu dele pored geografske i kulturnu i istorijsku bliskost, povlašćeni položaj države kandidata skoro izvesno bi bio (zlo)upotrebljen radi ostvarivanja državnih interesa. To nas uči i odnos Slovenije i Hrvatske tokom hrvatskog pregovaračkog procesa, ali i odnos Hrvatske prema Srbiji o čemu će kasnije biti više reči.

Od države kandidata se zapravo danas očekuje da funkcioniše kao članica EU, pre nego što to formalno i postane. Reformisati svoju privredu i društvo prema standardima EU, a onda dugo čekati na članstvo jako je teško ali i skupo. Državi su nametnuti mnogi izdaci, a pretpristupni fondovi su mnogostruko manji od strukturnih kojima imaju pristup države članice. Primera radi, Hrvatska će u narednih sedam godina moći da iskoristi 22 milijarde evra bespovratne pomoći iz Evropskog budžeta i zajedničkog paketa pomoći za države koje su najviše pogođene krizom uzrokovanom pandemijom. ${ }^{12} \mathrm{~S}$ druge strane, države "zapadnog Balkana” će u skladu sa ekonomsko-investicionim planom, koji je predstavljen početkom oktobra, raspolagati sa devet milijardi evra, pri čemu je nejasno koliko će od te sume činiti krediti. Okvirno govoreći, ove države imaju četiri i po puta više stanovnika nego što ima Hrvatska. Neke procene govore da Srbija kao kandidat godišnje izgubi između 1,2 i 1,3 milijarde evra godišnje, dok je iz IPA fondova za sedam godina povukla svega 1,4 milijarde evra. ${ }^{13}$ Zato je, između ostalog, neophodna izvesna perspektiva članstva svih država kandidata, jer bi u suprotnom mnoge sprovedene reforme ispostavile kao čist trošak, a za sada one predstavljaju samo oportunitetni trošak.

Kriterijumi za prijem Hrvatske u EU znatno su bili pooštreni u odnosu na pređašnje krugove proširenja. Proces pristupanja se nije formalno menjao, ali jeste sadržinski. Države koje su postale članice 2004. i 2007. godine vodile su pregovore $\mathrm{u}$ formatu 31 poglavlja, dok se Hrvatska, kao i Srbija, suočila sa 35 pregovaračkih poglavlja, pri čemu poslednje poglavlje pod nazivom „razno" predstavlja prostor za dodavanje onih uslova koji se ne mogu kategorizovati kao pravna tekovina EU. Dok je za ostale kandidate

12 „Srbija gubi 1,3 milijarde evra godišnje zato što nije u EU”, European Western Balkans, 23.7.2020. Dostupno na: https://europeanwesternbalkans.rs/srbija-gubi-13-milijardeevra-godisnje-zato-sto-nije-u-eu/, pristupljeno: 15.8.2020.

${ }^{13}$ Op. cit. 
(ali i za Hrvatsku) ovo poglavlje čisto formalnog karaktera, za Srbiju je ključno pa možda i egzistencijalno, jer podrazumeva „normalizaciju odnosa sa Prištinom", koja obuhvata i saradnju sa misijom EULEKS (EULEX KOSOVO). Pitanje Kosova je identitetsko pitanje i ne može se svrsteti u pravnu tekovinu EU, zato se nalazi u poglavlju koje nosi naziv „razno”. Prof. dr Nutčeva, sa Mastriškog Univerziteta, upozorava da zahtevi koje ispostavlja EU, a koji zadiru $u$ pitanje suverenita, nemaju isti stepen legitimiteta kao oni koji proističu iz Kopenhaških kriterijuma. ${ }^{14} \mathrm{O}$ težini ovog poglavlja za pregovarački proces govori podatak da je utvrđeno 36 prelaznih merila (interim benchmarks) koje treba ispuniti da bi se naknadno utvrdila merila za zatvaranje ovog poglavlja. U pregovorima sa Hrvatskom poglavlje 35, pored poglavlja 34 ,institucije”, nije sadržalo kriterijume koje treba ostvariti da bi se poglavlje zatvorilo, odnosno o kojima se ne vode pregovori, ali ih je svakako neophodno zatvoriti. U slučaju Srbije to je bilo jedno od prva dva poglavlja koja su otvorena u pregovorima sa EU, što još jednom ističe značaj pitanja Kosova za pregovarački proces. U praksi ovo poglavlje se uglavnom otvara među poslednjima. Kada govorimo o pregovaračkom procesu Hrvatske, u okviru poglavlja 35 se rešavalo pitanje Neumskog koridora, odnosno prolaska kroz Neum koji pripada Bosni i Hercegovini ali preseca teritoriju Hrvatske. Uspostavljen je poseban režim carinskih kontrola. ${ }^{15}$ Hrvatska je u okviru pregovora za poglavlje 24 dobila izuzeće od primene Zakona o šengenskim granicama na graničnim prelazima sa Bosnom i Hercegovinom i tako rešila pitanje Neumskog koridora. ${ }^{16}$ Pandemija virusa dodatno je aktuelizovala ovo pitanje. Hrvatski državljani mogli su prolaziti kroz Neum i uz ličnu kartu, nije im bio neophodan pasoš, ali bez zaustavljanja na području Federacije. Od kako je Savet ministara BiH doneo Odluku o proglašenju nastanka stanja prirodne ili druge nesreće na teritoriji Bosne i Hercegovine, hrvatski državljani moraju nositi pasoš, a u slučaju zaustavljanja preti im i dvonedeljni karantin. ${ }^{17}$ Nije na odmet napomenuti suštinsku razliku da je ovo bilateralni spor, dok je pitanje Kosova za Srbiju, prema i dalje važećem ustavu,

${ }^{14}$ Gergana Noutcheva, "EU conditionality and Balkan compliance: Does sovereignty matter?", Doctoral Dissertation, University of Pittsburgh, 2006. Dostupno na: http:/ /dscholarship.pitt.edu/7279/

${ }^{15}$ Pregovaračko stajalište Republike Hrvatske za međunarodnu konferenciju o pristupanju Republike Hrvatske Evropskoj uniji za poglavlje 35. „Ostala pitanja”, Vlada Republike Hrvatske, Ministarstvo vanjskih i europskih poslova. Dostupno na: http://www.mvep. $\mathrm{hr} /$ custompages/static/hrv/files/pregovori/4/35.pdf, pristupljeno: 18.11.2020.

${ }^{16}$ Pod izuzećem se podrazumeva trajno odustajanje od tekovina EU u specifičnom slučaju i ona se retko dešavaju.

${ }^{17}$ Odluka o proglašenju nastanka stanja prirodne ili druge nesreće na teritoriji Bosne i Hercegovine, Službeni glasnik BiH, 18/20. 
unutrašnje državno pitanje mada ga tako ne posmatraju članice koje su priznale secesiju tzv. države Kosova. U pregovaračkom okviru EU, i dokumentu pod nazivom „Opšta pozicija EU”, predstavljenom na prvoj međuvladinoj konferenciji na kojoj su otvoreni pregovori o pristupanju, možda se najilustrativnije vidi koliko je favorizovana normalizacija odnosa između Beograda i Prištine u odnosu na sve druge probleme koji opterećuju dobrosusedske odnose. ${ }^{18} \mathrm{U}$ ovom tekstu od svega 18 strana reč Kosovo se pominje čak 17 puta, dok se svi ostali svrstavaju u „dobrosusedske osnose". Na samom početku kaže se da „izgledi za pristupanje jačaju proces stabilizacije i pomirenja u regionu pokazujući na delu da proces proširenja dovodi do transformacije i stabilizacije u korist kako EU tako i regiona $\mathrm{u}$ celosti". Ovakvim činom EU pokušava implicitno da promeni sadržaj termina "dobrosusedski odnosi" i da izvrši dodatan politički pritisak na Srbiju da prizna secesiju tzv. države Kosovo. U osnovi principa dobrosusedskih odnosa nalazi se načelo suverene jednakosti država, te se odnosi Beograda i Prištine nikako ne mogu kvalifikovati kao dobrosusedski. Da situacija bude još složenija ni EU nije jedinstvena po ovom pitanju, pa tako pet njenih članica ne priznaje tzv. državu Kosovo. Hrvatska je zajedničkom izjavom sa Mađarskom i Bugarskom priznala tzv. državu Kosovo kao nezavisnu državu. Možemo reći da je glavna differentia specifica pregovaračkog procesa Hrvatske u tome što je poglavlje koje je ranije nosilo naziv Pravosuđe i unutrašnji poslovi, podeljeno na dva poglavlja: poglavlje 23 - Pravosuđe i osnovna prava, i 24 - Pravda sloboda i bezbednost. Ova poglavlja su, zajedno sa poglavljem 35, u slučaju Srbije suspenzivna poglavlja, što znači da nedostatak napretka u ovim oblastima sprečava otvaranje bilo kog drugog poglavlja. Hrvatska je prvi put blokirala Srbiju u otvaranju upravo poglavlja 23, a potom i 26 i 33. „Poučena” sopstvenim iskustvom Hrvatska je 2011. godine u Saboru usvojila Deklaraciju o promovisanju evropskih vrednosti u jugoistočnoj Evropi, te se ovom odlukom obavezala da neće blokirati susede zbog bilateralnih sporova koji ne potpadaju pod zakonodavstvo EU. ${ }^{19}$ Iz navedenog vidimo da se nije previše striktno pridržavala odredbi pomenute deklaracije.

Specifičnost hrvatskog procesa pristupanja ogleda se u uvođenju merila (opening benchmarks) za otvaranje određenih poglavlja. Uveden je set od 138 merila za otvaranje i zatvaranje poglavlja, što je za posledicu imalo najduži

\footnotetext{
${ }^{18}$ Konferencija o pristupanju Evropskoj Uniji - Srbija, Opšta pozicija EU. Dostupno na: https://www.media.srbija.gov.rs/medsrp/dokumenti/eu/uvodno_izlaganje_eu_o_pri stupnim_pregovorima_opsta_pozicija_eu.pdf, pristupljeno: 1.9.2020.

${ }^{19}$ Deklaracija o promicanju europskih vrijednosti u jugoistočnoj Europi, Narodne novine, br. 121, 28.10.2011. Dostupno na: https://narodne-novine.nn.hr/clanci/sluzbeni/ 2011_10_121_2379.html, pristupljeno: 2.9.2020.
} 
pregovarački proces jedne članice do sada (pet godina i osam meseci). ${ }^{20}$ Naravno, doprineli su i drugi faktori poput bilateralnih pitanja sa Slovenijom, ostavke premijera Ive Sanadera i drugo. Hrvatska se suočila sa blokadom u ukupno 13 poglavlja, pri čemu je Slovenija blokirala otvaranje osam i privremeno zatvaranje tri pregovaračka poglavlja. Situacija je kulminirala za vreme slovenačkog predsedavanja EU kada je otvoreno pitanje Zaštićenog ekološko-ribarskog pojasa, koji je uslovljen rešavanjem pitanja granice na moru. Tek nakon što je 2009. godine postignut dogovor o međunarodnoj arbitraži, Slovenija je odobrila nastavak pregovora. Indikativno je da se od Srbije traži da konačno reši sve svoje granične sporove pre ulaska u Uniju, a da se to od Hrvatske nije očekivalo, budući da je sam dogovor o arbitraži prihvaćen. Situacija je danas, čini se, još teža jer odluka Stalnog arbitražnog suda u Hagu doneta u korist Slovenije nije sprovedena, pa je Slovenija tužila Hrvatsku Sudu pravde EU zbog neprimenjivanja odluke pozivajući se na član 259 Ugovora o funkcionisanju Evropske unije. Hrvatska se odlukom Sabora povukla iz spora 2015. godine zbog ,teške povrede arbitražnog postupka” od strane Slovenije, pozivanjem na član 60 Bečke konvencije. Hrvatska, naravno, nije jedina država koja je ušla u EU sa graničnim sporovima, ali jeste poslednja pa ovakav zahtev prema Srbiji pokazuje pooštravanje kriterijuma. Još jedan takav primer oličen je u zahtevu da Srbija pristupi izradi akcionog plana za rešenje problema migranata i izbeglica, kao uslov za otvaranje poglavlja, a da ni sama EU nama takav plan. Upravo migrantska kriza pokazala je koliko je važna saradnja Srbije i Hrvatske, te da ima šire implikacije. Ne treba zaboraviti da je tokom 2015. godine došlo do ozbiljnog pogoršanja odnosa usled jednostranog zatvaranja granica od strane Hrvatske, pod optužbom da Srbija namerno preusmerava migrante na Hrvatsku. Zbog nereagovanja EU u nameri da sankcioniše Hrvatsku zbog ovakvih poteza, Srbija je uvela kontramere. Pretpostavlja se da je Evropska unija reagovala „,iza zatvorenih vrata”, ali u javnim istupanjima zvaničnika nije bilo osude ovog čina što svakako unosi zabrinutost. Treba konstatovati da pored toga što su reakcije blage, one su uvek reaktivne, što nam govori da se slične situacije mogu vrlo lako ponoviti. Da su reakcije bile oštrije i pravovremene to bi verovatno uticalo na prevenciju njihovog ponovnog javljanja u budućnosti.

Čini se da EU ostaje dosledna pre svega u procesu daljeg uslovljavanja Srbije, bez obzira na to kako će se to odraziti na pregovarački proces, što Anastakis naziva „rastućom agendom uslovljavanja” ${ }^{21}$ Činjenica da je teško održati reformski potencijal novih država članica, može da posluži kao

${ }^{20} \mathrm{U}$ praksi je bilo mnogo više merila pošto su mnoga sadržala i podkriterijume.

${ }^{21}$ Othon Anastasakis, The Europeanization of the Balkans, Brown Journal of World Affairs, Summer/Fall 2005, Vol. XII, Issue 1, p. 78. 
opravdanje za ovakvo delovanje EU. Države su svesne da su članstvom obezbedile više moći i da zbog toga ne moraju više da rade na reformama. Navodeći hipoteze pomoću kojih se meri uspešnost uslovljavanja Šimelfenig i Sedlmajer, između ostalog, navode i hipotezu članstva koja pretpostavlja smanjenu efikasnost politike uslovljavanja što je perspektiva članstva dalja. ${ }^{22}$ Na primeru Hrvatske i njenih težnji ka šengenskom prostoru vidimo da i kada država ispuni pretpostavljene uslove rezultat može da izostane, ili da se prolongira, što izaziva dodatno nezadovoljstvo. Jasno postavljeni kriterijumi moraju nedvosmisleno voditi do postavljenog cilja, u suprotnom je ceo proces iluzoran.

\section{Uloga EU u rešavanju otvorenih pitanja između Srbije i Hrvatske}

Srbija i Hrvatska su istovremeno krenule putem evropskih integracija, $\mathrm{a} u$ tom dugom procesu reformi možemo konstatovati da se na rešavanju otvorenih pitanja najaktivnije radilo onda kada je to bilo presudno za ulazak Hrvatske u EU, a da se ta dinamika znatno smanjuje nakon 2013. godine. U prilog tome govore i godišnji izveštaji o napretku koje sastavlja Evropska komisija. Poslednji izveštaj koji je objavljen početkom oktobra 2020. godine samo konstatuje da su sva otvorena pitanja između Srbije i Hrvatske i dalje bez napretka, ili kako se u jednom delu eksplicitno kaže „bez opipljivih rezultata" ${ }^{23}$ Pristupni pregovori glavni su podsticaj za rešavanje otvorenih pitanja koja su nastala kao posledica ratnih sukoba, a EU koja je upravo nastala kao mirovni projekat, trebalo bi da nastoji ispuniti prazninu koja nastaje nedostatkom političke volje dve države da ova pitanja rešavaju. Njena pasivna uloga može dugoročno uticati na stabilnost na Balkanu. I ono što je urađeno, poput potpisivanja „Deklaracije o unapređenju odnosa Srbije i Hrvatske" (kolokvijalnog naziva "Subotička deklaracija”), zanemarljivo je jer se odredbe ne sprovode. Subotička deklaracija usvojena je 20 godina nakon uspostavljanja diplomatskih odnosa Srbije i Hrvatske i predstavlja prvi dokument te vrste $\mathrm{u}$ kome su otvorena pitanja taksativno navedena, ali $\mathrm{u}$ isto vreme nisu ni iscrpljena. Da je EU zauzela ulogu aktivnog posrednika, kao što je to učinila u odnosima Beograda i Prištine, rezultati bi neupitno bili bolji. Stiče se utisak da je angažovanjem na normalizaciji odnosa Beograda i Prištine Evropska unija zapravo dostigla maksimum

${ }^{22}$ Todorović, nav.delo, 2011. str. 189.

${ }^{23}$ Commission staff working document, Serbia 2020 Report, Accompanying the Communication from the Commission to the European Parliament, the Council, the European Economic and Social Committee and the Committee of the Regions- 2020 Communication on EU Enlargement Policy, Brussels, 6.10.2020. Dostupno na: https:/ / ec.europa.eu/neighbourhood-enlargement/sites/near/files/serbia_report_2020.pdf, pristupljeno: 15.10 .2020 . 
kapaciteta svoje diplomatske i transformativne moći, te da su sva druga pitanja ostavljena u domenu bilateralnog rešavanja. ${ }^{24}$ Migrantska kriza, ali i pandemija virusa COVID19 su odlični pokazatelj stanja u EU, ali i značaja koje države Balkana imaju u bezbednosnom mozaiku Evrope. Opterećene bremenom ratova Srbija i Hrvatska evidentno nisu u stanju da naprave pomak u rešavanju otvorenih pitanja, jer političke elite profitiraju iz stanja "zamrznutog konflikta". Pored toga što ne zauzima konstruktivnu ulogu, Evropska unija ne pruža bilo kakav podstrek u cilju rešavanja ovih pitanja. Dodatno, demorališući faktor je i izostanak jasne perspektive članstva, što potvrđuje Strategija o proširenju na "Zapadni Balkan" koja je usvojena 6. februara 2018. godine. Od ovog dokumenta očekivalo se da će pružiti jasnu mapu na putu ka EU, ali i određene garancije za članstvo. Ipak, Strategija je samo konstatovala postojeće stanje, ali nije izostavila da spomene da normalizacija odnosa sa Prištinom mora da se dogodi "hitno". Neka tumačenja navode da je ovo zapravo olakšavajuća okolnost za Srbiju, jer ne postoji jasan vremenski okvir za rešavanje ovog pitanja. ${ }^{25} \mathrm{U}$ istoj tački 4 ove Strategije, pod nazivom „Pomirenje, dobrosusedski odnosi i regionalna saradnja - preduslovi za pristupanje", navodi se da EU ne može i neće da uvozi bilateralne sporove, posebno naglašavajući granične sporove, upravo zbog situacije u kojoj se nalaze Hrvatska i Slovenija. Ipak, Unija sav teret ostavlja državama da rešavaju bilateralno. Odricanje od odgovornosti vidi se $\mathrm{u}$ izjavi da „regionalna saradnja, dobrosusedski odnosi i pomirenje ne mogu se nametnuti spolja". Ovakav pasivan stav EU je jedan od glavnih razloga zašto do napretka u rešavanju otvorenih pitanja ne dolazi. Nakon toga, samit u Sofiji ne samo da nije potvrdio perspektivu članstva već se ona uopšte i ne pominje.

Unija raspolaže čitavim spektrom alata kojim bi mogla da potpomogne ovaj proces, kao što su uspostavljanje zajedničkih komisija (jer se pokazalo da su bilateralne neefikasne), savetodavna funkcija, stalne konsultacije, pravovremno i preventivno delovanje i tome slično. Pored toga, Unija može da izvrši značajan politički pritisak kako na Hrvatsku kao članicu tako i na Srbiju kao kandidata da se bave otvorenim pitanjima. Ona ipak, kao što vidimo bira, pasivnu ulogu jer je postavila jedan prioritetni cilj u kome igra ulogu aktivnog posrednika a to su odnosi Beograda i Prištine. Zanimljiv je stav Miše Đurkovića koji skrajnost politike proširenja vidi u činjenici da je „Nemačka ulaskom Hrvatske za koju se ozbiljno borila zaokružila prostor

${ }^{24}$ Vidi bliže: Maja Kovačević, ,"Ograničenja transformativne moći Evropske unije i Zapadni Balkan", Međunarodni problemi, Vol. LXXI, br.1/2019, str. 26-49.

${ }^{25}$ Vidi bliže na: Suzana Grubješić, „Dugi marš do Evropske unije”, Evropske sveske, 3/2018, str. 4-11. Dostupno na: http://www.emins.org/wp-content/uploads/2018/06/ Evropske-sveske-3-2018-Srbija-i-EU-Politi\% C4\%8Dki-i-ekonomski-odnosi.pdf, 64 pristupljeno: 22.8.2020. 
koji je sada zanima" ${ }^{26}$ Izbor ovakve strategije EU rezultira činjenicom da je čitav proces evrointegracija Srbije zarobljen napretkom $u$ odnosima Beograda i Prištine.

\section{Zaključna razmatranja}

EU je nastala kao mirovni projekat u posleratnoj Evropi s ciljem normalizacije odnosa između Nemačke i Francuske. Na primeru ovih država vidimo benefite međusobne saradnje u postkonfliktnom okruženju. Iako je Drugi svetski rat za sobom ostavio razarajuće posledice, obe države su relativno brzo pronašle interes u međusobnoj saradnji i time skrenule fokus svog delovanja sa ratnih zbivanja na međusobnu saradnju. Posledice građanskih ratova vođenih na teritoriji bivše Jugoslavije takođe su razarajuće i predstavljaju osnov svih otvorenih pitanja između Srbije i Hrvatske. Zaokret u međudržavnim odnosima, po ugledu na Nemačku i Francusku, čini se još uvek daleko a najviše zbog činjenice da se međusobna netrpeljivost propagira kroz javni diskurs. Ipak, Evropska unija predstavlja zajednički imenilac spoljnopolitičkih težnji dve države, i kao takva ima mogućnosti da potpomogne proces pomirenja, ali ona to ne čini, zbog čega rizikuje da ugrozi stabilnost na Balkanu. Podsetimo da odnosi Hrvatske i Srbije imaju svoje reperkusije i na stabilnost Bosne i Hercegovine, što bi trebalo dodatno da uveća napore EU ali i predmetnih država da se odnosi unaprede. Kapaciteti pregovaračkih procesa za rešavanje otvorenih pitanja nisu iskorišćeni. Deo odgovornosti leži i na Uniji koja se, preokupirana unutrašnjom reformom, te odgovornosti odriče i vraća ih $u$ domen bilateralizma, a vidimo da ni u Srbiji ni u Hrvatskoj ne postoji težnja da se ozbiljnije bavi otvorenim pitanjima, jer bi u suprotnom učinkovitost formiranih međudržavnih komisija bila veća. EU gubi na svojoj privlačnosti, između ostalog, i usled izostanka jasne perspektive članstva i ostavlja mesta za druge aktere na međunarodnoj sceni da taj jaz popune, što opet može dovesti do novih podela i diversifikacije interesnih zona, nasuprot pomirenju i integraciji. To se jasno vidi na primeru trenutne epidemiološke krize, koja je jasno pokazala da se države kandidati i dalje tretiraju kao periferija, a da ne govorimo o solidarnosti kao jednoj o vrednosti na kojima Unija deklarativno počiva. Kada govorimo o odnosima Srbije i Hrvatske, rešenje vidimo u brzom prijemu Srbije u članstvo, pri čemu joj ne bi bili stavljeni na raspolaganje i u punom kapacitetu svi benefiti članstva. EU mora da stimuliše države da se reformišu i nakon ulaska. Sadašnje delovanje EU višestruko je destimulišuće, a to se vidi i na primeru Hrvatske koja je

${ }^{26}$ Miša Đurković, „Evropska unija i Balkan u doba Junkerove komisije”, Međunarodna politika, LXVI, br. 1158-1159, str. 146. 
ispunila sve uslove da postane deo šengenskog prostora, što je potvrdila Evropska komisija, ali Slovenija najavljuje blokade u Savetu EU. Ukoliko su mir i stabilnost i dalje ključne vrednosti na kojima počiva proces EU integracija, Unija će morati ozbiljnije da se pozabavi stvaranjem mehanizama u cilju uspostavljanja dobrosusedskih odnosa, a ne da kao do sada reaguje reaktivno od slučaja do slučaja, pri čemu se problemi samo zaobilaze i skidaju sa trenutne agende ali se suštinski ne rešavaju. Srbija bi, s druge strane, trebalo češće i podrobnije da ispituje svoje interese i spoljnopolitičke ciljeve koji mogu obuhvatati, primera radi, zahtev za reviziju odredbi sporazuma o Stabilizaciji i pridruživanju koji ima višestruke negativne posledice po ekonomiju zemlje. Srbija je jako dugo izložena konkurenciji iz EU, a da ne može koristiti fondove za jačanje konkurentnosti. Takav zahtev bi mogao da bude inicijalni impuls za EU da preispita svoju ulogu i učini preko potrebne korake kako bi demonstrirala izvesnost stupanja u članstvo u bliskoj budućnosti.

\section{Bibliografija}

Anastasakis, Othon, "The Europeanization of the Balkans", Brown Journal of World Affairs, Summer/Fall 2005, Vol. XII, Issue 1.

Blagovčanin, Srđan, Evropska unija i Bosna i Hercegovina: Građenje države kroz proces evropskih integracija, Friedrich-Ebert-Stiftung, Sarajevo, 2016.

Commission staff working document, Serbia 2020 Report, Accompanying the Communication from the Commission to the European Parliament, the Council, the European Economic and Social Committee and the Committee of the Regions - 2020 Communication on EU Enlargement Policy, Brussels, 6.10.2020.

Consolidated Version of Treaty on European Union, Official Journal of the European Union, C 326/13, 26.10.2012, art.49.

Copenhagen European Council (21-22 June 1993), Conclusions of the Presidency, E.U. Bull., supp. 6/1993 (June 1993)

Deklaracija o promovisanju evropskih vrednosti u jugoistočnoj Evropi, Narodne novine, br. 121, 28.10.2011.

Dogovor o regionalnom predstavljanju i saradnji (2012), čl 3, Zvanična Internet prezentacija Vlade Republike Srbije.

Đurković, Miša, „Evropska unija i Balkan u doba Junkerove komisije”, Medunarodna politika, LXVI, br. $1158 \square 1159$.

European Commission Communication from the Commission to the European Parliament, the Council, the European Economic and Social 66 Committee and the Committee of the Regions- Enhancing the accession 
process - A credible EU perspective for the Western Balkan,Brussels, 5.2.2020.

Grubješić, Suzana, „Dugi marš do Evropske unije”, Evropske sveske, 3/2018. Kovačević, Maja, „Ograničenja transformativne moći Evropske unije i Zapadni Balkan", Međunarodni problemi, Vol. LXXI, br.1/2019.

Konferencija o pristupanju Evropskoj uniji - Srbija, Opšta pozicija EU.

Međak, Vladimir, i Budimir, Branko, Vodič kroz pristupanje Srbije Evropskoj uniji, ISAC Fond, Beograd, 2013, str. 22.

Nacionalni interes, godina VIII, vol. 15, br. 3/2012.

Noutcheva, Gergana, EU conditionality and Balkan compliance: Does sovereignty matter?, Doctoral Disertation, University of Pittsburgh, 2006.

Novaković, Igor, Albahari, Natan i Bogosavljević, Jovana, Analiza usaglašavanja Srbije sa spoljnopolitičkim deklaracijama i merama Evropske unije tokom 2018. godine, ISAC Fond, Beograd, 2019.

Odluka o proglašenju nastanka stanja prirodne ili druge nesreće na teritoriji Bosne i Hercegovine, Službeni glasnik BiH, 18/20.

Pregovaračko stajalište Republike Hrvatske za međunarodnu konferenciju o pristupanju Republike Hrvatske Evropskoj uniji za poglavlje 35. "Ostala pitanja”, Vlada Republike Hrvatske, Ministarstvo vanjskih i europskih poslova.

„Srbija gubi 1,3 milijarde evra godišnje zato što nije u EU”, European Western Balkans, 23. 7. 2020.

Teokarević, Jovan, „Skroman napredak ka sve manje poželjnoj Evropskoj uniji: Zapadni Balkan u evropskim integracijama 2015-2016. godine", Spoljnopolitičke sveske, broj: 1/16, str. 12.

The Declaration of the Zagreb Summit, European Commision, 24 November 2000.

Todorović, Jelena B., „Srbija i politika uslovljavanja Evropske unije”, Politička revija, godina (XXIII) X, vol=28 бp. 2 / 2011, str. 183-200. 


\title{
SPECIFICS AND COURSE OF THE ACCESSION NEGOTIATIONS OF SERBIA AND CROATIA FOR MEMBERSHIP IN THE EUROPEAN UNION - IMPLICATIONS FOR BILATERAL RELATIONS
}

\begin{abstract}
This paper presents an analysis of the differences between Serbia and Croatia's negotiation process for EU membership, especially those which have influenced the course and outcomes of the negotiations so far, as well as the bilateral relations between the two countries. Although the negotiations are a nominally suitable framework for resolving open issues between the candidate countries, due to the lack of political will, neither Serbia nor Croatia has used that capacity. Of all the neighbouring countries, Serbia has the most unsolved issues with Croatia (minority issues, missing persons, exiled and internally displaced persons, border demarcation on the Danube, successions and many others). The dynamics of relations have significantly changed since Croatia became a member in 2013, gaining a much-privileged position in regard to Serbia as a candidate. The main thesis of the paper is that the European Union has at the very least contributed to maintaining the status quo in Serbo-Croatian bilateral relations by raising the question of normalization of relations between Belgrade and Pristina above any other political questions, as well as bilateral relations with the countries in the region. It should be kept in mind that the relations between Serbia and Croatia are not only bilateral, but they also have their implications in Bosnia and Herzegovina, which further emphasizes the importance of improving bilateral relations for long-term peace and stability in the Balkans. The reasons for the Union's position can be found in its efforts to expand its influence in the region. With its engagement in resolving the Kosovo issue, and due to the reduction of its so-called transformative power, the EU has reached the maximum of its capacities, which is why it has taken a passive position when it comes to bilateral disputes. The double standards sporadically used by the EU when it comes to Serbia and Croatia were already visible in the Stabilization and Association Process that precedes the negotiation process, which will be discussed in the first part of the paper. The conditions for membership have not been formally changed, but they have changed in essence. These changes are one of the reasons for Serbia's slow progress towards EU membership, reasons which are basically of a political nature. These changes will be presented in the second part of the paper. In the end, we will try to evaluate whether this action of the EU and the negotiation process itself had a positive or negative impact on the development of good neighbourly relations between the two countries.
\end{abstract}

Keywords: European Union, Serbia, Croatia, negotiation process, accession negotiations, membership, criteria, bilateral relations. 